\title{
Flow Cytometry Protocol to Evaluate Ionizing Radiation Effects on P-Glycoprotein Activity
}

\author{
Neyliane Gonçalves dos Santos ${ }^{1 *}$, Ademir Amaral ${ }^{1}$, Mariana Brayner Cavalcanti ${ }^{1}$, Maria \\ Amélia Batista Neves ${ }^{2}$ and Cíntia Gonsalves de Faria Machado ${ }^{1,2}$ \\ ${ }^{1}$ Departamento de Energia Nuclear; Universidade Federal de Pernambuco; Av. Professor Luiz Freire, 1000; \\ 50740540; neylisantos@yahoo.com.br; Recife - PE - Brasil. ${ }^{2}$ Laboratório de Imunofenotipagem; Unidade de \\ Laboratórios Especializados; Fundação de Hematologia e Hemoterapia de Pernambuco; Rua Joaquim Nabuco, \\ 171; 52011900; Recife - PE - Brasil
}

\begin{abstract}
The aim of this work was to establish a protocol to evaluate ionizing radiation effects on P-glycoprotein (P-gp) activity. For this, human peripheral blood samples were irradiated in vitro with different doses and P-gp activity was analyzed for CD4 and CD8 T lymphocytes through rhodamine123-efflux assay by flow cytometry. By simultaneous employment of percentage and mean fluorescence index parameters, subject-by-subject analysis pointed out changes in P-gp activity for some individuals and irradiated samples. Based on this work, the proposed protocol was considered adequate for evaluating P-gp activity on cells after radioactive stress. Besides, this research suggests that P-gp activity could be an important factor to define patient-specific protocols in combined chemo- and radiotherapy, particularly when radiation exposure precedes chemical treatment.
\end{abstract}

Keywords: combined therapy, radiation effect, P-glycoprotein, multidrug resistance, functional analysis, flow cytometry

\section{INTRODUCTION}

One of the major limitations to efficacy of cancer chemotherapy (ChT) is multidrug resistance (MDR), which is characterized by cross-resistance of tumor cells to numerous structurally and functionally unrelated agents. Despite being multifatorial, MDR is often associated to P-glycoprotein (P-gp), which becomes the most attractive target to improve malignant cells control employing ChT (Stavrovskaya, 2000; Gottesman and Ling, 2006).
P-gp is a transmembrane protein that acts on cellular protection, transporting to out of cell a wide range of cytotoxic compounds. It represents a drawback for ChT because many clinically important therapeutic agents are its substrates (Sarkadi et al., 2006; Tandon et al., 2006).

Various endogenous and environmental stimuli can regulate P-gp (Sukhai and Piquette-Miller, 2000) and, therefore, can play a role in therapy success. That combination of chemotherapy (ChT) and radiotherapy (RT) has been widely employed as anticancer therapeutic strategies (Stewart and Saunders, 1997; Ferreira, 2007), and there is an

\footnotetext{
* Author for correspondence
} 
additional interest in evaluating ionizing radiation effect on regulation of this protein. Although several studies have addressed to this theme (McLean; Hill, 1993; Hill et al., 1994), few have studied the consequences for P-gp activity.

$\mathrm{P}$-gp activity is assessed by functional tests, which based itself on measurement of P-gp substrates post-uptake efflux in the presence and absence of a P-gp inhibitor, being substrate retention inversely proportional to protein activity (Beck et al., 1996; Marie et al., 1997). These analyses are commonly carried out by flow cytometry, a tool that allows to measure several physical and biological properties of a large number of suspended cells in fluid based on detection of light scattering and fluorescence emitting (Switzer and Garrity, 1999; Bacal and Faulhaber, 2003).

In this context, this work has been designed in order to establish a protocol to evaluate ionizing radiation effect on P-gp activity by flow cytometry.

\section{MATERIALS AND METHODS}

\section{Subjects and sampling}

Proceeding in agreement with recommendations from Hematology and Hemotherapy Foundation of Pernambuco (HEMOPE)'s ethics committee, samples of whole peripheral blood were obtained from five healthy women (coded as S1, S2, S3, S4 and S5), with a age range from 20 to 40 years old. A total of $30 \mathrm{ml}$ of blood was collected by venipuncture into $\mathrm{K}_{3}$ EDTA-containing vacutainer tubes from each donor.

\section{Irradiation process}

$10 \mathrm{ml}$ aliquot of total sample was used as control (no irradiated), while the two remaining aliquots were separately exposed to 0.5 and 2.0 Gy of gamma radiation from a Theratron 780 Cobalt- 60 therapy unit at $251 \mathrm{cGy} / \mathrm{min}$ dose rate.

\section{Cell suspension process}

Peripheral blood mononuclear cells (PBMC) were obtained by density gradient using Ficoll (density $<1.077 \mathrm{~g} / \mathrm{ml}$, GE Healthcare, Sweden), according to manufacturer's recommendations. Cell pellet was resuspended in RPMI-1640 medium plus 5\% fetal calf serum (both reagents by Cultilab, Brazil) to a final concentration of $5 \times 10^{6}$ cells $/ \mathrm{mL}$.

\section{Rhodamine123-efflux assay}

P-gp activity was determined by Rhodamine 123 (Rh123)-efflux, a fluorescent P-gp substrate, according to technique described previously (Chaudary et al., 1992; Machado et al, 2003). Briefly, PBMC ( $1 \times 10^{6}$ cells/tube) were incubated with Rh123 (Sigma, St. Louis, USA), final concentration equal to $200 \mathrm{ng} / \mathrm{mL}$, for $20 \mathrm{~min}$, at $37^{\circ} \mathrm{C}$. Following centrifugation, cells were washed and incubated with Rh123-free medium, in absence or presence of VPM (Sigma, USA), at final concentration of $10 \mu \mathrm{M}$, for 1.5 hours, at $37^{\circ} \mathrm{C}$ and at $4^{\circ} \mathrm{C}$, respectively.

\section{Lymphocytes identification}

After being washed with Rh123-free medium, cells were incubated with specific monoclonal antibodies for $20 \mathrm{~min}$, in the dark, at $4^{\circ} \mathrm{C}$. PhycoerythrinCyanine5.5 [PECy5.5]-conjugated anti-CD3 (clone 2A3, FKBiotecnologia, Rio Grande do Sul, Brazil) was used to identify $T$ lymphocytes, and phycoerythrin (PE)-conjugated CD4 (clone SK3, Becton Dickinson, San Jose, CA, USA) and -CD8 (clone B9.11, Immunotech, France), to identify T-helper and T-cytotoxic lymphocytes. Following incubation, cells were washed and resuspended in VPM-containing RPMI medium.

\section{Flow cytometry}

FACSCalibur flow cytometer (Becton Dickinson, USA) equipped with argon-ion laser (wavelength setting $488 \mathrm{~nm}$ ) and Cell Quest software version 3.1 (Becton Dickinson, USA) was used to cell analysis. From each aliquot, 50,000 events (cells) were acquired. Light scattering was detected in linear scale, being recorded in a two-parameter dot plot, while fluorescence was detected in logarithmic scale and recorded in two-parameter dot plots and in histogram.

Correlation between forward scatter (FSC) and side scatter (SSC) signals (proportional to size and cellular complexity, respectively) allowed identification of lymphocytes-corresponding events, which were delimited within R1 electronic gate. These events were analyzed as for PE (peak emission wavelength $575 \mathrm{~nm}$ ) and PECy5.5 (690 $\mathrm{nm}$ ) fluorescence, detected in channel 2 (FL2) and channel (FL3), respectively, with those doublepositive events gated in R2.

Finally, Rh123 fluorescence $(535 \mathrm{~nm})$ was recorded from target population (CD4 or CD8 T subset), being detected in channel 1 (FL1). 
Percentage data was obtained from FL1/FL2 dot plots, which also allow visualizing Rh123-efflux dynamic by comparison between aliquots incubated in presence and absence of VPM. Mean fluorescence index (MFI) data was calculated according to standard recommendations (Marie et al., 1997), from readings of Rh123-associated mean fluorescence intensity on both samples and presented on a histogram.

\section{Statistical analysis}

Statistical analyses were conducted in the software BioEstat 5.0. Mean, standard deviation and variation coefficient were obtained by descriptive statistical of each group analyzed (control and irradiated) and significant differences were analyzed by
Mann-Whitney non-parametric U-test, with $\alpha=0.05$.

\section{RESULTS}

Figure 1 shows box plots presenting values for Pgp activity for control and irradiated (0.5 and 2.0 Gy) group in CD4 and CD8 T lymphocytes.

Table 1 presents P-gp activity analysis subject-bysubject, comparing each irradiated sample with control sample of same individual.

For some of these cases, variation identification only was possible analyzing simultaneously percentage and MFI data.
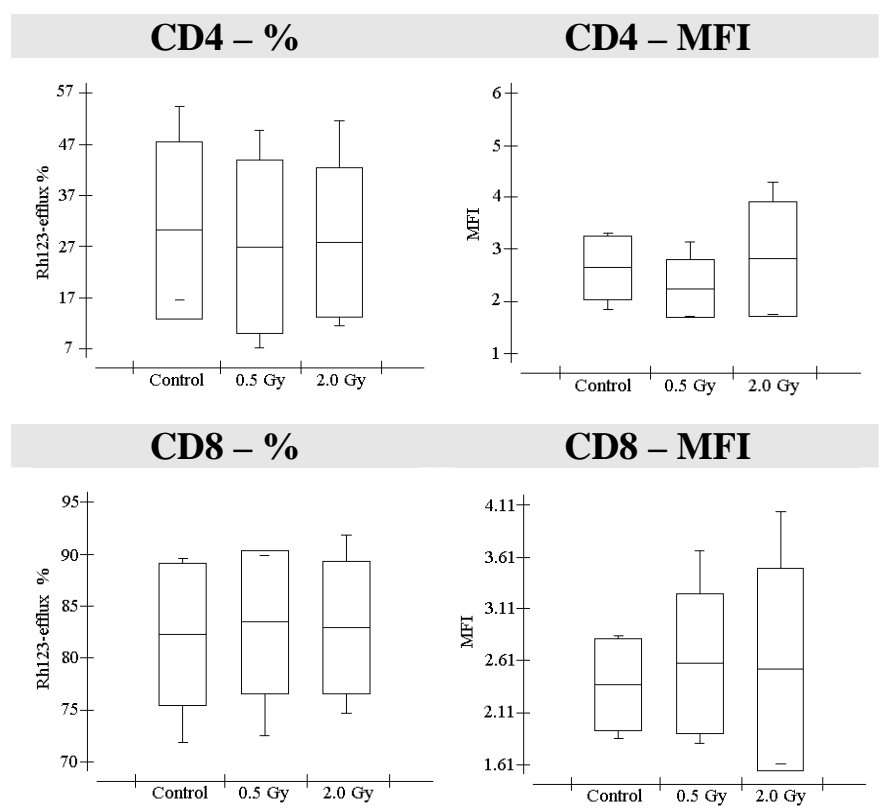

Figure 1 - Box plots presenting P-gp activity data (percentage and MFI) in CD4 and CD8 T lymphocytes, for control, 0.5 Gy- and 2.0 Gy-irradiated sets.

Table 1 - P-gp analysis subject-by-subject (irradiated sample versus control sample).

\begin{tabular}{cccccc}
\hline & \multicolumn{3}{c}{ CD4 } & \multicolumn{3}{c}{ CD8 } \\
\cline { 2 - 6 } Subject & \multicolumn{3}{c}{ Dose (Gy) } & $\mathbf{0 . 5}$ & $\mathbf{2 . 0}$ \\
\cline { 2 - 6 } & $\mathbf{0 . 5}$ & $\mathrm{X.0}$ & $\mathrm{X}^{*}$ & $\mathrm{X}^{*}$ & $\mathrm{X}^{*}$ \\
S1 & $\mathrm{X}$ & & & \\
S2 & & & & $\mathrm{X}$ \\
S3 & & $\mathrm{X}$ & & \\
S4 & $\mathrm{X}$ & & $\mathrm{X}$ & & \\
S5 & & &
\end{tabular}

$\mathrm{X}$ : differences greater than $20 \% * \mathrm{MDR}$ susceptibility. 


\section{DISCUSSION}

As this work was carried out to evaluate effects of a physical agent (ionizing radiation) on $\mathrm{P}$-gp activity, control here, adopted as for some biological parameters (age, drugs exposition) which can influence results, was essential, being accepted only healthy individuals, on age range where P-gp activity does not present a large variation. Although there is no evidence of relevance about sex genders, only women were chosen, as a way to minimize variables.

Employment of the gold standard fluorescent dye and the transporting inhibitor most indicated (Wang et al., 2006; Vasconcelos et al., 2007) was essential to warrant sensitivity and reproducibility of methodology, which showed be reliable for assessing P-gp functional parameter, even after irradiation stress.

Several biological models may be used to evaluate ionizing radiation effect on P-gp activity. However, peripheral blood lymphocytes appear as a promising candidate because present P-gp activity (Chaudary et al., 1992) and have already been widely used to investigate radioinduced changes due to its radiosensitivity and sampling ease (IAEA, 2001; Dainiak, 2002; Amaral, 2005).

This study focused on $\mathrm{T}$ lymphocytes, which present good quantitative representation (Valensi, 2005), high radiosensitivity (Mori et al., 2005) and exuberant Rh123-efflux by P-gp activity (Drach et al., 1992). Procedures to interest population gating during flow cytometry analysis contribute still more to certify the proposed protocol as reproducible, with events R2-gated illustrating due the interest subset, with values corresponding those of literature (Zago et al., 2004) and similar between samples groups (control and irradiated), indicating that analyses were carried out for the same cell group, for all doses.

In control samples, a variation on P-gp activity among individuals was observed, being greater in CD4 than in CD8. This data is connected with others works (Coon et al., 1991; Drach et al., 1992; Meaden et al., 2002; Machado et al., 2003), which evidence a normal variation among subjects and lymphocytes groups, on the same proportions here identified. Differences between Cd4 and CD8 subset can indicate that CD8 is more stable to $\mathrm{P}$-gp regulators influence (as physical agent in question) that CD4.

Contrasting each irradiated set $(0.5$ and $2.0 \mathrm{~Gy})$ with the control one, no statistically significant differences were found for P-gp activity, to both $\mathrm{T}$ subsets. However, as significance levels varied in a large range $(0.35 \leq \alpha \leq 1.00)$, was carried out an analysis of data on a subject-by-subject basis. Difference greater than $20 \%$ for P-gp activity were identified in S1, S2, S4 and S5 subjects, without direct correlation with absorbed dose or $\mathrm{T}$ subset. Besides, data point out emerging parameter MFI as important in functional in nature applications, may avoid a false positive or false negative medical test results.

To appearance of this protocol, P-gp activity emerges as potential prognostic parameter to patient-specific treatments employing combined protocols, especially when RT prior to ChT, as in preparation process for marrow bone transplant and solid tumors treatment. Changes in P-gp activity from $\mathrm{T}$ lymphocytes inducted or increased by ionizing radiation interaction could, for instance, affect immune or pharmacological response in transplant recipients or cancer patients by alteration in intracellular concentrations of many immunosuppressive medications or drugs, rendering patients resistant to therapy despite adequate blood levels (Begg, 1997; Drach et al., 1996; Donnenberg et al., 2001; Vasquez et al., 2005).

Thus, this protocol can be employed to analyze Pgp functional behavior at different dose levels and for others lymphocyte subsets, including a greater number of individuals in order to confirm these preliminary results. On the other hand, for evaluating P-gp activity of other type of cells that exhibit P-gp activity, the protocol established in this work can be used with minor adaptations.

\section{ACKNOWLEDGMENTS}

The authors would like to thank the Centro de Radioterapia de Pernambuco (CERAPE-Brazil), for providing laboratory facilities, to the Conselho Nacional de Desenvolvimento Científico e Tecnológico (CNPq-Brazil), for financial support, and to Ian Edwards, for English review.

\section{RESUMO}

O objetivo deste trabalho foi estabelecer um protocolo para avaliar o efeito da radiação ionizante na atividade da glicoproteína-P (gp-P). 
Para isto, amostras de sangue periférico humano foram irradiadas in vitro com diferentes doses, e a atividade da gp-P foi analisada para os linfócitos T CD4 e CD8 através do ensaio do efluxo da rodamina123 por citometria de fluxo. Por emprego simultâneo dos parâmetros de porcentagem e índice médio de fluorescência, a análise indivíduo por indivíduo apontou mudanças na atividade da gp-P para alguns indivíduos e amostras irradiadas. Com base neste trabalho, o protocolo proposto foi considerado adequado para avaliar a atividade da gp-P em células após estresse radioativo. Além disso, esta pesquisa sugere que a atividade da gp-P poderia ser um importante fator para definir protocolos paciente-específicos envolvendo quimio e radioterapia, particularmente quando a exposição à radiação precede $\mathrm{o}$ tratamento químico.

\section{REFERENCES}

Amaral, A. (2005), Physical and biological dosimetry for risk perception in radioprotection. Braz Arch Biol Technol., 48, 229-234.

Bacal, N. S.; Faulhaber, M. H. W. (2003), Aplicação prática em citometria de fluxo, Atheneu, São Paulo.

Beck, W. T.; Grogan, T. M.; Willman, C. L.; CordonCardo, C.; Parham, D. M.; Kuttesch, J. F.; Andreeff, M.; Bates, S. E.; Berard, C. W.; Boyett, J. M.; Brophy, N. A.; Broxterman, H. J.; Chan, H. S. L.; Dalton, W. S.; Dietel, M.; Fojo, A. T.; Gascoyne, R. D.; Head, D.; Houghton, P. J.; Srivastava, D. K.; Lehnert, M.; Leith, C. P.; Paietta, E.; Pavelic, Z. P.; Rimsza, L.; Roninson, I. B.; Sikic, B. I.; Twentyman, P. R.; Warnke, R.; Weinstein, R. (1996), Methods to detect P-glycoprotein-associated multidrug resistance in patients tumors: consensus recommendations. Cancer Res., 56, 3010-3020.

Begg, A. C. (1997), Individualization of radiotherapy. In: Basic clinical radiobiology, 2nd. ed., Ed. Steel, G. G., Arnold, London, pp. 234-245

Chaudary, P. M.; Mechetner, E. B.; Roninson, I. B. (1992), Expression and activity of the multidrug resistance P-glycoprotein in human peripheral blood lymphocytes. Blood, 80, 2735-2739.

Coon, J. S.; Wang, Y.; Bines, S. D.; Markham, P. N.; Chong, A. S. F.; Gebel, H. M. (1991), Multidrug resistance activity in human lymphocytes. Human Immunol., 32, 134-140.

Dainiak, N. (2002), Hematologic consequences of exposure to ionizing radiation. Exp. Hemat., 30, 513528.

Donnenberg, V. S.; Buckart, G. J.; Griffith, B. P.; Jain, A. B.; Zeevi, A.; Donnenberg, A. D. (2001), Pglycoprotein $(\mathrm{P}-\mathrm{gp})$ is upregulated in peripheral $\mathrm{T}$ - cell subsets from solid organ transplant recipients. $J$ Clin Pharmacol., 41, 1271-1279.

Drach, D.; Zhao, S.; Drach, J.; Mahadevia, R.; Gattringer, C.; Huber, H.; Andreeff, M (1992), Subpopulations of normal peripheral blood and bone marrow cells express a functional multidrug resistant phenotype. Blood, 80, 2729-2734.

Drach, J.; Gsur, A.; Hamilton, G.; Zhao, S.; Angerler, J.; Fiegl, M.; Zojer, N.; Raderer, M.; Haberl, I.; Andreeff, M.; Huber, H. (1996), Involvement of Pglycoprotein in the transmembrane transport of interleukin-2 (IL-2), IL-4, and interferon- $\gamma$ in normal human T lymphocytes. Blood, 99, 1747-1754.

Ferreira, P. R. F. (2007), Tratamento combinado em oncologia/quimioterapia, hormonioterapia, radioterapia, Artmed, Porto Alegre.

Gottesman, M. M.; Ling, V. (2006), The molecular basis of multidrug resistance in cancer: the early years of P-glycoprotein research. FEBS Letters, 580, 998-1009.

Hill, B. T., Whelan, R. D. H., Hurst, H. C., McLean, S. (1994), Identification of a distinctive P-glycoproteinmediated resistance phenotype in human ovarian carcinoma cells after their in vitro exposure to fractionated X-irradiation. Cancer, 73, 2990-2999.

International Atomic Energy Agency (IAEA) (2001). Cytogenetic analysis for radiation dose assessment: $a$ manual. Technical report series n. 405, IAEA, Viena.

Machado, C. G., Calado, R. L., Garcia, A. B., Falcão, R. P. (2003), Age-related changes of the multidrug resistance P-glycoprotein function in normal human peripheral blood T lymphocytes. Braz J Med Biol Res., 36, 1653-1657.

Marie, J. P.; Huet, S.; Faussat, A. M.; Perrot, J. Y.; Chevillard, S.; Barbu, V.; Bayle, C.; Boutonnat, J.; Calvo, F.; Campos-Guyotat, L.; Colosetti, P.; Cazin, J. L.; de Cremoux, P.; Delvincourt, C.; Demur, C.; Drenou, B.; Fenneteau, O.; Feuillard, J.; GarnierSuillerot, A.; Genne, P.; Gorisse, M. C.; Gosselin, P.; Jouault, H.; Lacave, R.; Le Calvez, G.; Léglise, M. C.; Léonce, S.; Manfait, M.; Maynadié, M.; MerleBéral, H.; Merlin, J. L.; Mousseau, M.; Morjani, H.; Picard, F.; Pinguet, F.; Poncelet, P.; Racadot, E.; Raphael, M.; Richard, B.; Rossi, J. F.; Schlegel, N.; Vielh, P.; Zhou, D. C.; Robert, J. (1997), Multicentric evaluation of the MDR phenotype in leukemia. Leukemia, 11, 1086-1094.

McLean, S.; Hill, B. T. (1993), Evidence of posttranslational regulation of P-glycoprotein associated with the expression of a distinctive multiple drugresistance phenotype in Chinese hamster ovary cells. Eur J Cancer, 29, 2243-2248.

Meaden, E. R.; Hoogard, P. G.; Khoo, S. H.; Back, D. G. (2002), Determination of P-gp and MRP1 expression and function in peripheral blood mononuclear cell in vivo. J Immunol Methods., 262, 159-165. 
Mori, M.; Benotmane, M. A.; Tirone, I.; HooghePeters, E. L.; Desaintes, C. (2005), Transcriptional response to ionizing radiation in lymphocyte subsets. Cell Mol Life Sci., 62, 1489-1501.

Sarkadi, B.; Homolya, L.; Szakács, G.; Varandi, A. (2006), Human multidrug resistance $\mathrm{ABCB}$ and ABCG transporters: participation in a chemoimmunity defense system. Physiol Rev., 86, 1179-1236.

Stavrovskaya, A. A. (2000), Cellular mechanisms of multidrug resistance of tumor cells. Biochemistry (Moscow), 65, 95-106.

Sukhai, M.; Piquette-Miller, M. (2000), Regulation of the multidrug resistance genes by stress signals. $J$ Pharm Pharm Sci., 35, 2, 268-280.

Switzer, R. L.; Garrity, L. F. (1999), Experimental biochemistry, W. H. Freeman and Company, New York.

Stewart, F. A.; Saunders, M. I. (1997), Combined radiotherapy and chemotherapy: clinical applications and evaluation. In: Basic clinical radiobiology, Ed. Steel, G. G., Arnold, London, pp. 195-202.

Tandon, V. R.; Kapoor, B.; Bano, G.; Gupta, S.; Gillani, Z.; Gupta, S.; Kour, D. (2006), P- glycoprotein: pharmacological relevance. Indian $J$ Pharmacol., 38, 13-24.

Valensi, F. (2005), Morphologie des cellules sanguines normales. EMC Hémat., 2, 1-13.

Vasconcelos, F. C.; Cavalcanti Júnior, G. B.; Silva, K. L.; Meis, E.; Kwee, J. K.; Rumjanek, V. M.; Maia, R. C. (2007), Contrasting features of MDR phenotype in leukemias by using two fluorochromes: implications for clinical practice. Leuk Res., 31: 445-454.

Vasquez, E. M.; Petrenko, Y.; Jacobssen, V.; Sifontis, N. M.; Sankary, H.; Benedetti, E. (2005), An assessment of P-glycoprotein expression and activity in peripheral blood lymphocytes of transplant candidates. Transplantation Proc., 37, 175-177.

Wang, Y.; Hao, D.; Stein, W.; Yang, L. (2006), A kinetic study of Rhodamine123 pumping by $\mathrm{P}$ glycoprotein. Bioch Biophys Acta., 1758, 1671-1676.

Zago, M. A.; Falcão, R. P.; Pasquini, R. (2004), Hematologia: fundamentos e prática. Atheneu, São Paulo, pp. 1081 